\title{
The ALA-Ford Foundation Burma Projects: A Report
}

WHEN, on October 11, the Burmese Embassy notified the Ford Foundation that the Government of the Union of Burma "desires to finance the expenditures of all Burmese scholars who are currently studying abroad till completion of their studies with effect from 1st October, 1962," the programs of library development financed by the Ford Foundation and administered by the American Library Association were officially ended. Beginning in 1958 American librarians had spent approximately three years at each of the two universities of Burma, the University of Rangoon and the University of Mandalay; nine Burmese had been sent to library schools in the United States; some twentyfive to thirty young people had received onthe-job training in clerical and subprofessional library tasks; modern library equipment had been installed in the libraries of both universities; the existing libraries recataloged and thousands of books and periodical volumes added. The American librarians involved in these two projects were Jay E. Daily, who spent three years at the University of Mandalay, and Paul $\mathrm{H}$. Bixler and the writer, who spent two years and thirteen months, respectively, at the University of Rangoon. The projects, which involved at Mandalay reorganization of the university library, and setting up a divisional library for the Faculty of the Social Sciences at Rangoon, were assigned to the Association of College and Research Libraries as the administrative focal point within the ALA organization. The Mandalay project was limited originally to one year; an extension of two years was granted in 1960 . The Rangoon project began in 1958 and was scheduled to run for two years; an extension was granted for the years 1961-63. Thus, when the Government of the Union of Burma notified the Ford Foundation on April 12, 1962, that it no longer desired aid from foreign organizations and asked that all Foundation personnel leave the country within six months, the Mandalay project had just about reached its terminal point and the Rangoon project had still another year to go.

\section{Personnel}

The agreements signed by the university officials, the Ford Foundation, and ALA required that Burmese be sent abroad for professional training in library science so that the libraries could be maintained and operated according to modern procedures. Two young men from Mandalay were sent, one to the University of Michigan, the other to George Peabody College; U Kyaw is expected to complete his work at Michigan in January 1963. U Kaung Nyunt who left Burma a few days before the government suspended foreign aid scholarships on March 16 , 1962, will probably need to spend another academic year at Peabody before receiving the degree in library science. The University of Rangoon Agreement provided for seven students; three to serve as the professional staff of the Social Science library and four, under the extended project, for the staff of the university library. U Than Lwin, who was chosen to be chief librarian of the Social Science library, had to return home for reasons of health after a few weeks at Syracuse University in the fall of 1960. Concurrently, Daw Hlaing Hlaing Cho, who had operated a departmental library in the Social Science Faculty, entered Peabody College and upon her return to Rangoon in September 1961 began work as cataloger in the Social Science library. In September 1962 , three young people returned to Rangoon with degrees in library science. U Myo Lwin, Peabody, is employed temporarily in the university library since no position was created for him, as originally planned, in the Social Science library; U Ohn Pe, Michigan, selected to be chief librarian of the Social Science library after the return of $\mathbf{U}$ Than Lwin, may be working part time in the Social Science library, certainly he is devoting all or a major portion of his time teaching psychology; and Daw Myint Myint Khyn, 
Indiana, has returned to her position of branch superintendent (supervisor of clerical staff) in the Social Science library. The two catalogers from the university library, Daw Khin Khin Ohn and U Maung Maung, are still enrolled at the University of Illinois and will return to their posts upon completion of their work in January 1963. Of the nine persons sent abroad by the two projects four have returned to Burma with degrees in library science and we have reason to believe that three of them are at present engaged full time in the libraries of the University of Rangoon; four are still engaged in study in this country and we expect all of them to earn degrees and return to their posts in the libraries of the two universities from which they are on leave. When the scholarship program was suspended we were busily engaged trying to get approval for another young woman, Daw Kyawt Kyawt, to come to the United States; these efforts brought to our attention the fact that the scholarship program had been suspended.

In addition to these persons who received professional training, a much larger number of young Burmese received in-service training which has helped them to move into better paying jobs and, in some cases, into permanent jobs. Some of the persons on the university payrolls were granted additional pay from the projects; upon notice that the projects would be terminated these young people began immediately to seek other positions which paid salaries similar to those which they had been receiving. Others who were hired full time by the projects were able to compete successfully for permanent positions because, they claimed, of the experience they had had in "an American type" of library. Experience in the use of the typewriter, experience in filing, keeping materials in order, improved use of the English language-these were definite assets gained by these young people as by-products of their work with the projects. One young man was hired by a government library, another by an embassy where the use of English was important.

Only in this area of personnel did the University of Rangoon fail to implement a condition of the Agreement. In the original Agreement the university promised to "make arrangements for permanent staff to manage the (Social Science) library. This staff shall include one member of the staff of the Fac- ulty of Social Sciences at the rank of lecturer who will be assigned as librarian on a parttime basis; two permanent assistant librarians of the rank of assistant lecturer; and other clerical assistants." The clerical assistants were provided immediately, but the professional positions have not, to our knowledge, been created as yet. Even so, the Social Science library is not without professional personnel; at least two of our trainees are engaged there on a full-time basis-one receiving pay from the department of economics and the other being paid as supervisor of the library clerical staff.

\section{Book Collections}

The book collections in both institutions have been materially improved; in both institutions the existing libraries had to be recataloged. At Mandalay, with some seventeen thousand volumes in the university library, Dr. Daily set up a production line, divided the cataloging process into its simplest essentials and placed as much of the work on the shoulders of his clerical staff as he possibly could. His original assignment required that the job be completed in one year! With an extension of two years, he and $U$ Htun Aung, the university librarian, with their staff of clerical workers, cataloged and reorganized the entire university library system: the Medical College library, the library of the College of Agriculture, the library of the Intermediate College at Magwe, and set up the library of a new Intermediate College at Taunggyi. At the close of the project the University of Mandalay could boast of a fully-cataloged and well organized library system of some forty-five thousand volumes. Books had been taken out of locked cabinets and placed on steel shelves fully available to all students and teachers. Even before installing the steel shelving, imported from India, Daily had unlocked the cabinets and virtually established an open-shelf library. Moreover, at the close of the project there had been established, as an adjunct to the library, an audio-visual theater supplied with seats, audio-visual equipment, phonorecords, and exhibition space.

At Rangoon, Bixler found several small departmental libraries with a total of some seventy-five hundred volumes "variously cataloged and cared for." Some of the books were cataloged in one way, some in another, 
and others not cataloged at all. Bixler decided to use Library of Congress catalog cards because he felt that the Dewey numbers and subject headings would be useful in the future when catalogers may be inexperienced and LC cards unavailable; the cards would furnish a complete form of catalog annotation; and their use would reduce typing - and the incidence of typing errorsto a minimum. Good fortune made it possible for Bixler to secure the services of a young American woman, a graduate of the Syracuse School of Library Science, who was residing in Rangoon. During 1958-60 most of the books from the departmental libraries were transferred to the new Social Science library, cataloged, and made available for use; others were transferred from at least one department in 1961. To these were added sufficient books and bound periodicals so that the Social Science library in June 1962 comprised some eighteen thousand volumes. Each of the six departments of the faculty assigned a teacher to assist in book selection and during the course of the project several teachers returned from graduate study in England and the United States. To a man these persons gladly entered into the book selection process, so much so that we can feel confident that the Social Science library will serve the needs of the students and teachers of the faculty as well as one would find in a similar situation anywhere.

It may be interesting to point out some differences between the book collections in these two libraries. First of all and least important in this connection, is the fact that the Social Science library is limited to the materials needed by the six departments that comprise the Faculty of Social Science, while at Mandalay the library serves the entire university. The most important difference centers around materials in the Burmese language. In the Social Science library less than 1 per cent, perhaps, of the material is published in Burmese, chiefly government publications, some of which are also published in English. At Mandalay, however, a very high percentage of the books are in Burmese; there are several reasons why this situation prevails. The library at Mandalay serves the entire university while the Social Science library at Rangoon serves only a segment of the university community; at Rangoon the university library attempts to collect all ma- terials published in the country. Very important is the fact that Mandalay is a more "Burmese" city than Rangoon; while there are many students at both universities who would prefer books in Burmese to books in English and who find the use of English quite a chore, the percentage of these students is probably much higher at Mandalay. It is planned that at some future date the subject catalog at Mandalay will have all headings in Burmese; at the present time subject headings are not typed on the individual cards, they are typed only on guide cards, and cards for each book on a subject are filed after the guide card bearing that heading. When the subjects are translated into Burmese, the headings can then be typed on the cards as we do in our American libraries. The visiting librarian at Mandalay had a task which his colleagues at Rangoon were spared-the cataloging of palm-leaf manuscripts and parabaiks, sources of Burmese history and literature, an area of particular interest to $\mathrm{U}$ Thein Han, university librarian at Rangoon.

\section{FaCILITIES AND EQUiPMENT}

The agreements, in both instances, required that the university concerned furnish such equipment as was available locally and that project funds would be used to purchase books, periodicals, supplies, and the equipment which had to be purchased abroad. Tables, chairs and desks for both libraries were built by local carpenters. Card catalog cabinets and book trucks were imported from the United States for Rangoon, but at Mandalay the "hardware" for these items was imported while the actual cabinets and trucks were built locally. Similarly with the steel shelving, the shelving for Rangoon was imported from the United States, while that for Mandalay was imported from India. The result of this procedure is that the Social Science library at Rangoon presents a more American, more Western, look and the university library at Mandalay looks more Burmese, more Asian. Again, this appearance conforms, even though unintentionally, to the difference between the two cities.

The main library at Mandalay is housed in one large room, the top floor of a sizeable rectangular building, Razak Hall. The Social Science library at Rangoon consists of four rooms on the ground (first) floor of the 
recently constructed Faculty of Social Science building situated at the northern end of the University Estate, overlooking one of the two large lakes which contribute to the recreational facilities and beauty of Rangoon. One room is equipped only with chairs, tables and desks and is used by students for study purposes after the library has closed. The main library reading room and the reference room have a central core of steel stacks, surrounded by chairs, tables and desks; the fourth room is the workroom and it is here that all of the technical processes are performed. Air conditioners were installed in the reference room and dehumidifiers in the workroom and main library reading room in order to combat dampness and the work of insects. A microfilm reader and cabinets for storing reels of the New York Times and several journals have been placed in the reference room.

\section{Benefits of the Projects}

Aside from the usual benefits that accrue to any institution that undergoes a program of library improvement, there are several other benefits, tangible and intangible, that have come to all concerned. The Americans and members of their families had an opportunity to gain a clearer understanding and appreciation of the living conditions and problems of a "developing" country; this writer was about halfway home before he realized that for more than a year he had not seen store windows filled with electrical appliances and many other items that we in the United States may purchase on almost any street corner whenever we have the urge -and the money. Several young Burmese have had the opportunity of travel in both the East and the West, the privilege of living in a university community, of studying under teachers who use methods different from those to which they are accustomedthis can be a benefit, if wisely used. Certainly, their horizons have been greatly widened. As indicated above, even those clerical and subprofessional workers who were hired by the projects have enjoyed certain material benefits, even though not commensurate with those enjoyed by the young people who studied abroad. The faculty members at both institutions had another opportunity to practice cooperation and working together; as each department head gave up his library, he could see more clearly the advantages of teamwork and of larger units of library resources and services. It is hoped that at Rangoon, especially, the Social Science library will serve as a model for bringing together more of the twenty-odd library units that still exist in the other faculties of the university.-Joseph H. Reason.

\section{"Creative" Circulation at Stanford}

STANFORD UNIVERSITY librarians last summer discovered that a completely printed, bound and cataloged pair of books called "Pataphysical Meditations" by "Dargoman C. Basqui" was circulating in their library system. Proper catalog cards were even inserted into the files, so the book could be used by students. A note included says that eight of the twelve pages were swept up accidentally and burned, leaving only one 156-word poem, which parodies avant garde poetry. An editor's note explains "Pataphysics is the science of imaginary solutions, which symbolically attributes the properties of objects, described by the virtuality, to their lineaments." The book was, apparently, printed by "The Homecraft Press, Cornucopia, Ore.-You Find 'Em, We Bind 'Em." 


\section{Grants Awarded by ACRL Committee}

At ITS EIgHTH ANNUAL MEeting held at the University of Michigan, November 25-27, 1962, the ACRL Grants Committee made grants to seventy college and university libraries. In addition, the committee awarded individual grants to two librarians in support of research. Applications for assistance amounting to approximately $\$ 330,000$ were submitted by 294 institutions; librarians requested more than $\$ 40,000$ for the purchase of the New York Times on microfilm.

All of the grants, except two or three, were given for the purchase of books and periodicals to support honors programs, area studies, and the various fields of study from art to zoology. St. Mary's Dominican College was given money with which to collect material concerning the Second Vatican Council; Wilmington College will purchase books to be used in connection with a series of convocations and seminars which deal with the fundamental issues facing students as "citizens of the nation and the world." Fisk University was given funds to aid in refurbishing a collection of drawings and paintings depicting African life and African types. Ten libraries were given grants to assist in the purchase of one or more parts of the Library of Congress Catalog and the National Union Catalog. The grants range in amount from $\$ 220$ to $\$ 1,500$; the average of the institutional awards is slightly less than $\$ 600$. Libraries in thirty-five states in all regions of the country have been awarded grants this year. In New England and the East twelve awards were made to libraries in five states; in the South nineteen libraries in twelve states were given grants; in the Midwest twenty-six libraries in eleven states; and in the West thirteen libraries in seven states.

The Grants Program was made possible this year by the following companies and corporation foundations: Kennecott Copper Corporation; McGraw-Hill Publishing Company; The National Biscuit Company Foundation; Olin Mathieson Chemical Corporation; Pitney-Bowes, Inc.; Time, Inc.; United States Steel Foundation, Inc.; and $\mathbf{H}$. W. Wilson Co.
The ACRL Grants Program was initiated in 1955 with a grant of $\$ 30,000$ from the U.S. Steel Foundation. The program is directed toward the general needs of private colleges and universities for developing their library collections, improving the quality of library service to higher education through fundamental research in librarianship, and otherwise aiding in the best use of the most modern teaching and learning materials. More than $\$ 328,000$ has been distributed since inception of the program.

Members of the Grants Committee for 1962/63 are: Richard W. Morin (chairman), librarian, Dartmouth College, Hanover, N.H.; Helen M. Brown, librarian, Wellesley College, Wellesley, Mass.; Wen Chao Chen, librarian, Kalamazoo College, Kalamazoo, Mich.; Mark M. Gormley, librarian, University of Wisconsin-Milwaukee, Milwaukee, Wis.; Richard B. Harwell, librarian, Bowdoin College, Brunswick, Me.; David Kaser, director, Joint University Libraries, Nashville, Tenn.; Humphrey G. Bousfield (consultant), librarian, Brooklyn College, Brooklyn, N.Y.; Katharine M. Stokes (ex officio), librarian, Western Michigan University, Kalamazoo, Mich.; and Joseph H. Reason (ex officio), 50 East Huron Street, Chicago.

\section{2/63 ACRL GRANTS}

Adrian College, Adrian, Mich. (Mrs. Dorothy M. Shipman) $\$ 255$.

Bates College, Lewiston, Me. (Iva W. Foster) $\$ 500$.

Birmingham-Southern College, Birmingham, Ala. (Margaret H. Hughes) $\$ 400$.

Blue Mountain College, Blue Mountain, Miss. (Mrs. Florence F. Taylor) $\$ 400$.

Chaminade College of Honolulu, Honolulu, Hawaii (Bro. Charles C. Cummingsmith) $\$ 500$.

Clarke College, Dubuque, Iowa (Sister Mary Harrietta) $\$ 800$.

Colorado Woman's College, Denver, Colo. (Pearce S. Grove) $\$ 600$.

University of Dallas, Dallas, Tex. (Sister Mary Dorothea) $\$ 700$.

Eastern Baptist College, St. Davids, Pa. (Ethel Klingerman) $\$ 700$.

Emory and Henry College, Emory, Va. (Helen Power) $\$ 1,000$. 
Fisk University, Nashville, Tenn. (Arna Bontemps) $\$ 500$.

Franklin and Marshall College, Lancaster, Pa. (Herbert B. Anstaett) $\$ 800$.

Goshen College, Goshen, Ind. (James R. Clemens) $\$ 500$.

HAmpden-Sydney College, Hampden-Sydney, Va. (Paul L. Grier) $\$ 750$.

Hobart and William Smith Colleges, Geneva, N.Y. (Elizabeth Thalman) $\$ 500$.

College of the Holy Names, Oakland, Calif. (Sister Raphael Mary) $\$ 500$.

Huntingdon College, Montgomery, Ala. (R. Glenn Massengale) $\$ 500$.

La Sierra College, La Sierra, Calif. (D. Glenn Hilts) $\$ 1,200$.

Lawrence College, Appleton, Wis. (H. A. Brubaker) $\$ 700$.

Lewis and Clark College, Portland, Ore. (Laurence E. Tomlinson) $\$ 275$.

Lincoln University, Lincoln University, Pa. (Donald C. Yelton) $\$ 1,000$.

Manchester College, North Manchester, Ind. (Ruth Coblentz) \$500.

Marylhurst College, Marylhurst, Ore. (Sister Mary Imeldine) $\$ 500$.

Mary Manse College, Toledo, Ohio (Sister Virginia Marie) $\$ 400$.

Marymount College, Salina, Kan. (Sister Agnes Virginia Engelbert) $\$ 300$.

Methodist College, Fayetteville, N.C. (Alva W. Stewart) $\$ 450$.

Millikin University, Decatur, Ill. (Donald D. Hendricks) $\$ 400$.

Mount Mary College, Milwaukee, Wis. (S. M. Angela Merici) $\$ 800$.

Muhlenberg College, Allentown, Pa. (John S. Davidson) $\$ 350$.

Nebraska Wesleyan University, Lincoln, Neb. (Ted Kneebone) $\$ 600$.

Northwest Nazarene College, Nampa, Idaho (Edith E. Lancaster) $\$ 400$.

College of Notre Dame, Belmont, Calif. (Sister Mary Justine) $\$ 500$.

Occidental College, Los Angeles, Calif. (Tyrus G. Harmsen) $\$ 500$.

College of the Ozarks, Clarksville, Ark. (Mrs. Lucile L. Murphy) $\$ 600$.

Parsons College, Fairfield, Iowa (Homer Lee Sutton) $\$ 400$.

Pennsylvania Military College, Chester, Pa. (Lee C. Brown) $\$ 800$.

Phillips University, Enid, Okla. (Eugene T. Curtis) $\$ 240$.

Pikeville College, Pikeville, Ky. (Wesley Pinkerton) $\$ 800$.

University of Puget Sound, Tacoma, Wash. (Warren L. Perry) $\$ 500$.

ROCHESTER INSTITUTE OF TECHNOLOGY, Rochester, N.Y. (Thomas E. Strader) $\$ 1,000$.
College of St. Benedict, St. Joseph, Minn. (Sister Imogene) $\$ 1,300$.

St. John's College, Santa Fe, N.M. (Charlotte Fletcher) $\$ 500$.

St. John's University, Collegeville, Minn. (Benjamin J. Stein) $\$ 800$.

St. Joseph's College, Rensselaer, Ind. (Charles Banet) $\$ 300$.

St. Mary's Dominican College, New Orleans, La. (Sister Mary Reginald) $\$ 400$.

St. Michael's College, Winooski, Vt. (Vincent B. Maloney) $\$ 500$.

St. Peter's College, Jersey City, N.J. (Edmond FX. Ivers) $\$ 700$.

St. Procopius College, Lisle, Ill. (Adolph E. Hrdlicka) \$220.

College of St. Rose, Albany, N.Y. (Sister Anna Clare) $\$ 500$.

College of St. Thomas, St. Paul, Minn. (Clyde E. Eddy) $\$ 500$.

San Diego College for Men, San Diego, Calif. (Charles Dollen) $\$ 1,000$.

SAN Diego College for Women, San Diego, Calif. (Mother Kathleen McDevitt) $\$ 1,500$.

Simpson College, Indianola, Iowa (William W. Garton) $\$ 650$.

Sioux Falls College, Sioux Falls, S.D. (Hans O. Zenner) \$885.

Spring Hill College, Mobile, Ala. (Robert J. Zietz) $\$ 500$.

Sterling College, Sterling, Kan. (Lucile Lukens) $\$ 200$.

Stetson University, DeLand, Fla. (Bob L. Mowery) $\$ 1,000$.

College of Steubenville, Steubenville, Ohio (Demetrius Shenk) $\$ 400$.

Tarkio College, Tarkio, Mo. (Jeanette Huston) $\$ 1,000$.

TAYLOR UnIVERSITY, Upland, Ind. (Alice K. Holcombe) $\$ 650$.

Tennessee Wesleyan College, Athens, Tenn. (Claryse D. Myers) $\$ 600$.

Texas Lutheran College, Seguin, Tex. (Warren Lussky) $\$ 400$.

Transylvania College, Lexington, Ky. (Roemol Henry) $\$ 400$.

Union College, Barbourville, Ky. (J. B. McFerrin) $\$ 425$.

Wells College, Aurora, N.Y. (Helen L. Sears) $\$ 600$.

Western College for Women, Oxford, Ohio (Esther Duggleby) $\$ 500$.

Westmar College, LeMars, Iowa (Esther Merkle) $\$ 400$.

Westminster College, Fulton, Mo. (P. G. Morrison) $\$ 500$.

Wheeling College, Wheeling, W. Va. (Josephine Savaro) $\$ 500$.

Wilmington College, Wilmington, Ohio (Willis H. Hall) $\$ 600$. 
Research grants for bibliographic projects were awarded to Paul Kaufman and Michael M. Reynolds. Kaufman, consultant in bibliography, University of Washington, Seattle, was awarded $\$ 1,000$ to make a comprehensive study of book clubs in eighteenth century England; Reynolds, assistant director of li- braries, West Virginia University, Morgantown, was awarded $\$ 475$ to compile and publish a guide to sources of theses and dissertations and research in progress.

Remington Rand grants for new furniture and equipment available through the Library Bureau will be announced at a later date.

\title{
University of North Carolina Revised Program for M.S. in L.S. Degree
}

\begin{abstract}
A REVISED PROGRAM for the M.S. in L.S. degree in the School of Library Science at the University of North Carolina at Chapel Hill will become effective in the summer session of 1963. Greater flexibility in the prescribed content of the graduate program will make possible a better balance between academic and professional preparation, it is believed by school curricula experts. The school anticipates that the new structure will make possible more complete articulation of its graduate program with undergraduate programs in library science which are approved under ALA/NCATE standards as adopted by the ALA Council in January, 1959.
\end{abstract}

In addition to affording better balance of professional and nonprofessional content in a student's total program, the new curriculum insures that each student will complete a common professional core of study whatever his ultimate professional objective, and that he will have maximum opportunity to specialize in his chosen field of librarianship without prejudice to his basic professional preparation. For all students who can meet the admission requirements, the time required to obtain the degree will be reduced from three full semesters or equivalent to two full semesters plus a summer session. Students who hold graduate degrees in other disciplines may be able to complete their professional preparation in no more than two semesters of residence.

Essential changes in the new curriculum include: 1) increasing the prescribed graduate content to thirty-nine semester hours unless the student already holds a graduate degree, when the total normally will be thirty to thirty-three hours; 2) substitution of a core curriculum which may be completed at the advanced undergraduate or the graduate level; 3) modification of the formal minor requirement in an academic discipline, in favor of a plan under which the number and choice of academic courses and their fields can be selected in closer harmony with a student's needs and his professional objectives; 4) substitution of a research paper in conjunction with the required course in research methodology for the present thesis; and 5) a final comprehensive examination to include the entirety of a student's professional preparation. No changes in requirements for admission, completing residence, demonstrating reading knowledge of at least one foreign language, or in the transfer of graduate credit from other universities are being made. 